\title{
PReS-FINAL-2297: Atmospheric pollution: influence on disease activity in childhood-onset systemic lupus erythematosus patients
}

\author{
LM Campos $^{1 *}$, EGC Fernandes ${ }^{1}$, CA Silva ${ }^{1}$, AA Braga ${ }^{2}$, AM Sallum$^{1}$, SCL Farhat ${ }^{1}$ \\ From 20th Pediatric Rheumatology European Society (PReS) Congress \\ Ljubljana, Slovenia. 25-29 September 2013
}

\begin{abstract}
Introduction
Environmental factors, such as atmospheric pollution, may trigger the inflammation in adult systemic lupus erythematosus (SLE) patients. However, the role of atmospheric pollution and disease activity in childhoodonset systemic lupus erythematosus (C-SLE) population was not reported at this moment.
\end{abstract}

\section{Objectives}

To investigate the association between changes in daily concentrations of air pollutants in São Paulo metropolitan region and disease activity in C-SLE patients.

\section{Methods}

This was a longitudinal panel study including 410 consecutive medical visits in $22 \mathrm{C}$-SLE patients (ACR criteria). They were followed at the Pediatric Rheumatology Unit, Children's Institute, Faculdade de Medicina da Universidade de Sao Paulo, Brazil, between 2005 and 2010. Disease activity was evaluated according to Systemic Lupus Erythematosus Disease Activity Index 2000 (SLEDAI-2K), and the patients were divided arbitrarily in two groups: with disease activity (SLEDAI $>8$ ) and without disease activity (SLEDAI $<8)$. The São Paulo State Environmental Agency (CETESB) provided daily concentrations of inhaled particulate matter $\left(\mathrm{PM}_{10}\right)$, sulfur dioxide $\left(\mathrm{SO}_{2}\right)$, nitrogen dioxide $\left(\mathrm{NO}_{2}\right)$, ozone $\left(\mathrm{O}_{3}\right)$ and carbon monoxide $(\mathrm{CO})$. Meteorological variables, such as the minimum temperature and relative humidity, were obtained from the Institute of Astronomy and Geophysics of the University of São Paulo. Generalized estimation equation (GEE) model were used for binomial distribution to assess the

Paediatric Rheumatology Unit, Children's Institute, University of São Paulo, São Paulo, Brazil

Full list of author information is available at the end of the article impact of these measurements in the SLEDAI 2K score, considering the fixed effects for repetitive measurements, and adjusted for erythrocyte sedimentation rate, C-reactive protein, prednisone and/or immunosuppressant use, presence of infection 20 days before the medical appointment, minimum temperature and relative humidity. The results were expressed in relative risk (RR) and confidence interval (CI) of $95 \%$.

\section{Results}

410 consecutive medical visits were evaluated in $22 \mathrm{C}$ SLE patients (20 girls), with a mean of 19 visits/patient (4-30). The mean current age at the time of evaluation was 15.3 years (10.8-19.0). The mean age at C-SLE diagnosis was 10.3 years (6-12) and the mean age at disease duration was 5.3 years ( 7 months- 11 years). Interquartile range increases of $\mathrm{PM}_{10}\left(25.2 \mu \mathrm{g} / \mathrm{m}^{3}\right)$, CO $\left(0.8 \mu \mathrm{g} / \mathrm{m}^{3}\right)$, and $\mathrm{NO}_{2}\left(102 \mu \mathrm{g} / \mathrm{m}^{3}\right)$ were associated with increases of 1.74 (CI of 95\% 1.28-2.39), 1.37 (CI 95\% 1.12-1.67) and 1.11 (CI 95\% 1.02-1.21) in the risk of SLEDA-2K score score $>8)$, respectively, 13 days after the exposure to these pollutants. The four days $\mathrm{PM}_{10}$ cumulative effect (from lag13 to lag16) increased the risk of outburst of SLE in 65\% (CI 95\% 1.06- 2.75). In contrast, ozone and $\mathrm{SO}_{2}$ did not show a significant effect on the SLEDAI-2K score.

\section{Conclusion}

Variations in air pollution may influence disease activity in C-SLE patients. Therefore, oxidative stress may be an important trigger of inflammation in this systemic autoimmune disease.

\section{Disclosure of interest}

None declared. 


\section{Authors' details}

'Paediatric Rheumatology Unit, Children's Institute, University of São Paulo,

São Paulo, Brazil. ${ }^{2}$ Laboratory of Experimental Air Pollution, University of São

Paulo, São Paulo, Brazil.

Published: 5 December 2013

doi:10.1186/1546-0096-11-S2-P287

Cite this article as: Campos et al: PReS-FINAL-2297: Atmospheric

pollution: influence on disease activity in childhood-onset systemic

lupus erythematosus patients. Pediatric Rheumatology 2013 11(Suppl 2):

P287.

Submit your next manuscript to BioMed Central and take full advantage of:

- Convenient online submission

- Thorough peer review

- No space constraints or color figure charges

- Immediate publication on acceptance

- Inclusion in PubMed, CAS, Scopus and Google Scholar

- Research which is freely available for redistribution

Submit your manuscript at 